\title{
SCIARA TRITICI, COQ. A FLY INJURIOUS TO SEEDLINGS.
}

By F. W. EDWARDS, B.A., F.E.S.,

AND C. B. WILLIAMS, M.A., F.E.S.

(Published by permission of the Trustees of the British Museum.)

UNTIL comparatively recent years few or no instances were known of damage to plants by fly larvae of the genus Sciara, and even in some recorded cases it was supposed that the injury caused by the Sciara larvae was only of a secondary nature, and that they only attacked parts of plunts where decay had already begun to set in owing to the attacks of some other pest. Recent investigations by several observers in the United States have, however, shown that in a number of instances the damage must be directly attributed to the larvae of some species of Sciara.

No definite records have been published on this subject in Britain, and it has therefore been thought worth while to issue the following notes on a species of Sciara which certainly causes damage to potted plants in this country. Added interest is given by the fact that the species in question has not previously been recorded in Great Britain, or even in Europe, though it is quite uncertain where it had its original home.

In the autumn of 1911 specimens of a Sciara were sent me for identification by Mr C. B. Williams, from Merton, Surrey, where they were damaging Primula seedlings. At that time I was unable to identify these specimens with any described European species, and they were in consequence put on one side. The question was reopened in June of the present year (1915) when living specimens of the same species were received from $\mathrm{Mr}$ W. H. St Quintin, of Rillington, Yorks, whose young orchid plants had suffered from their attacks. I then studied the literature more carefully and found that the specimens were without 
any doubt identical with the Sciara tritici described by Coquillet from North America in 1895.

Coquillet made positive statements as to the injury caused by the larvae to young whest plants. He says (Insed Life, Vol. vII, 1895, p. 407): "On March 17, 1885 a large number of adults issued from a jar containing plants of this kind that had attained a height of from 6 to 8 inches. They already indicated an unhealthy growth by a more or less yellowish appearance, and an examination of their roots revealed the fact that these had been severely injured by the larvae, many of which were still present, and were observed to feed upon the roots and interior of the stems both below the surface of the soil as well as in the interior of the stems a short distance above the surface. As many as eight larvae were sometimes found in one of the stems, and they had also penetrated the kernels of wheat from which the plants sprang; inany of the smaller rootlets had also been devoured, or more or less injured, by them."

Mr St Quintin was equally definite in attributing the damage to the Sciara larvae', as the following extract from his letter will show:

"It is causing great trouble and loss to raisers of exotic orchids and seems to be on the increase. The books written only a few years back do not allude to it amongst the insect pests which trouble urchids under cultivation. Certainly here, though we have been raising orchids (from seed) for about 8 years, until the last three or four we have never noticed it. It is particularly troublesome this spring, but it seems to fly all the year round, at any rate whenever we have young orchid plants at a particular stage, we find it in our seedling house. This house is kept very moist, and with a temperature of from $70^{\circ}-80^{\circ} \mathrm{F}$. according as the day is dull or sunny.

"When the little plants have acquired the real root, the fly does not trouble them, but at the very early stage when the plant draws its nourishment from root-hairs it cuts these off and starves the plant. When it has destroyed all the little plants in a pot it tarns to the Sphagnum moss and devours that.

"Fumigation kills the insect when it is on the wing, but it appears to emerge at all hours of the day, and does not mind the fumigation in the larval and pupal stages.

"It seems a question whether the fly came with the Osmunda fibre,

1 Some of these larvae have been handed to Mons. D. Keilin, who will describe them in his forthooming work on the early stages of the Diptera. 
which has within the last few years been more or less used in the compost for raising orchids from seed, or in the Sphagnum moss, which has always been used since the first experiment in raiging epiphytic orchids. The Osmunda fern fibre comes from N. America, the Sphagnum used is British."

In the case of these orchids the possibility should not be overlooked that at least some of the damage may be caused by springtails (Collembola). These insects were present in large numbers in the contents of some pots sent to the British Museum by Mr St Quintin, and it is worth recalling that in 1902 Prof. F. V. Theobald recorded a case of injury to odling orchids by springtails in Surrey (vide First Report on Economic Zoology, Brit. Mus. Nat. Hist., p. 110). In this lastmentioned case specimens of a Sciarid fly (Zygoneura sp.) were found in addition to the Collembola, but Theobald had little doubt that the damage was really caused by the latter. In Mr St Quintin's pots both the Collembola and the Sciara larvae were much more numerous in the Osmunda compost than in the Sphagnum.

Prof. Theobald has recently had a species of Sciara injuring tomato seedlings at Wye, and at my request he kindly sent me specimens of the fly concerned; contrary to expectation they proved not to be $S$. tritici, although they were not in sufficiently good preservation to be determined accurately.

Sciara tritici is a small fly about $2 \mathrm{~mm}$. long, differing from most of its congeners in the reddish coloration of the thorax, somewhat darker towards the margins when viewed from above; the abdomen is rather darker than the thorax. Its most obvious distinguishing feature however-by which it may be separated from all the other members of the genus so far described-is the possession of a whitish-yellow stripe on the dark brown pleurae, connecting the bases of the front. and middle coxae. There is also a whitish spot below the shoulder. It belongs to the group II.A.1.C.b of Winnertz's monograph. Coquillet, in the paper cited, gives a good description and figures the larva, pupa and adult; from these the species will be easily recognised, but it may be pointed ont that the figure of the wing is not accurate, the subcostal cell being made much too narrow.

$$
\text { F. W. E. }
$$

Thx Britsh Museuz of Natural History, November, 1915. 
Seedlings, particularly Primula and Campanula, under glass at this Institution, have, at various times during the past few years, suffered slightly from the attacks of small Dipterous larvae. The larvs was of the Mycetophilid type, very long and slender with a shining black head, and adults bred out and captured in the hot-houses have been identified by Mr Edwards as Sciara tritici as mentioned above.

The larvae are found usually below the surface of the soil where they eat the roots and the collar of the seedlings. Frequently the root was eaten right across below the collar so that the dying rosette of the seedling would be found resting on the soil unattached to the roots. Sometimes a cotyledon or a small leaf which was touching the surface of the soil would be damaged on its lower surface. Pupae were found also just below the surface and the empty skins projecting slightly above having either worked their way there before emergence or been dragged to this position by the emerging fly. The adults were found commonly running about on the surface of the soil, on the sides of the boxes and pots containing the seedlings and occasionally resting underneath the boxes. They ran actively, were reluctant in taking to flight and their flight was not powerful.

Three larvae, quite large on the 9th January, 1912, were given a small piece of root of a larger Campanula which they fed on readily, removing the softer tissues and leaving the fibrous vascular bundles. They spun a slight web and pupated on the same web on the 19th, 20th, and 21 st of January. The pupa was pale shining yellow and $2 \mathrm{~mm}$. long by $0.7 \mathrm{~mm}$. broad. A day or two after pupation the eyes began to darken. After four days the anterior end of the pupa darkened and this gradually spread till the whole, just before emergence, was dark brown. One adult emerged on the 25th and two on the 27th, giving a pupal stage of 6-7 days.

In emergence the pupal skin split along each side of the antennae, leaving the covering of these free except at the base where it was joined to the ventral surface of the pupa case.

Another dipteron, Scatella quadrata, is nearly always associated with Sciara tritici but as yet na damage has been traced to it.

A Sciara larva, indistinguishable from the above, was found out of doors in the root of an old Campanula. It pupated among the fibres of the root but unfortunately died in the pupal stage.

The pest has been kept under control by regular fumigation of the houses, chiefly with fumigants containing nicotine. It was also 


\section{Sciara tritici, Coq. A Fly Injurious to Seedlings}

largely destroyed by the sterilization of the soil by heating which was tried experimentally for some time. This method, however, was abandoned as it was not found satisfactory for other reasons.

It is suggested by Mr St Quintin (see above) that the species in his case was introduced from the United States in Osmunda fibre. In our houses there were a few orchids growing in Osmunda fibre and it is possible that they might have come in this from some other locality in England. It is probable that it will be found widely distributed in greenhouses in this country.

$$
\text { C. B. W. }
$$

The John Insms Hortictltural Institution, MmRTON, SURREY. November, 1915. 